\section{Reply to the response given by N. Basavaraja to Knight et al. 2013a\&b}

\section{J.D. Marcus Knight ${ }^{1}$, Ashwin Rai ${ }^{2} \&$ Ronald K.P. D'souza ${ }^{3}$}

${ }^{1}$ Flat L', Sri Balaji Apartments, 7th Main Road, Dhandeeswaram, Velachery, Chennai, Tamil Nadu 600042, India

${ }^{2}$ Department of Fisheries Microbiology, College of Fisheries, Yekkur, Mangalore, Karnataka 575002, India

${ }^{3}$ Department of Applied Zoology, Mangalore University, Mangalagangothri, Mangalore, Karnataka 574199, India

${ }^{1}$ jdmarcusknight@yahoo.co.in (corresponding author), ${ }^{2}$ winrai@yahoo.com, ${ }^{3}$ kevinroni@yahoo.com

We appreciate the response of Basavaraja (2014). However, it is obvious that his first set of comments was made overlooking our follow up paper on the identity of Hypselobarbus pulchellus published in the Journal of Threatened Taxa on 26 December 2013 (Knight et al. 2013b). Most of his first set of queries are already addressed in the above paper, nevertheless we will reply to his questions based on Knight et al. (2013b).

Day (1870) based his original description of $H$. pulchellus on a single stuffed specimen and mentioned 30 lateral line scales. Later Day (1878) redescribed the species based on two specimens and reported a lateral line scale count as 30-32. Even though Day (1878) does not mention whether the specimens were stuffed or not, the original description (Day 1870) was based on stuffed specimens and scale loss in stuffed specimen is quite inevitable. However, the specimens examined in this study had 32-34+1-2 lateral line scales. It is highly probable that one or two scales behind the nape or on the caudal fin base could have fallen off in the specimen that Day (1870) used for the original description. Moreover, the dry skin mount of $\mathrm{H}$. pulchellus by Francis Day at the National History Museum, London (BMNH 1889.2.1.4328) does appear to have more than 32 lateral line scales (Knight et al. 2013b). Contrary to Basavaraja's observations, the dry skin mount clearly has an indentation on the nape and behind the opercle which clearly highlights scale loss. Moreover, the scales

DOI: http://dx.doi.org/10.11609/JoTT.o3910.5419-20 Date of publication: 26 January 2014 (online \& print)

Manuscript details: Ms \# 03910 | Received 08 January 2014

Citation: Knight, J.D.M., A. Rai \& R.K.P. D'souza (2014). Reply to the response given by N. Basavaraja to Knight et al. 2013a\&b. Journal of Threatened Taxa 6(1): 5419-5420; http://dx.doi.org/10.11609/JoTT.03910.5419-20

Copyright: ( K Knight et al. 2014. Creative Commons Attribution 3.0 Unported

License. JoTT allows unrestricted use of this article in any medium, reproduc-

tion and distribution by providing adequate credit to the authors and the source of publication.

on the caudal fin base on the dry mount are fused and indiscernible. Therefore, we are quite sure that the dry mount had more than 32 lateral line scales when it was alive.

Contrary to Basavaraja's claim that we have not examined specimens from Tunga, ZSI/SRC F

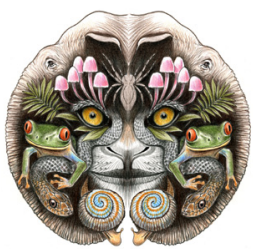

ISSN

Online 0974-7907 Print 0974-7893

\section{OPEN ACCESS} 8753 , collected by Jayaram examined by us is from Tunga. The morphometrics and meristics of that specimen conformed to the other specimens from Sita and similar to the other specimens of $H$. pulchellus collected from Sita River, Karnataka, the specimen from Tunga River, Shimoga collected by Jayaram had $33+2$ lateral line scales. Unlike Basavaraja's assertion, the type locality of H. pulchellus is indeed South Canara (Day 1878).

Despite the fact that Basavaraja persistently mentions that the range in lateral line scale count is not acceptable, wide range in lateral line scale counts is quite common in the genus Hypselobarbus. In our experience, and other recent publications (Ali et al. 2013) clearly record this aspect in two other Hypselobarbus species. Moreover, the type series of species such as Neolissochilus wynaadensis have a remarkable scale range highlighting the fact that large lateral line scale ranges are not only seen in Hypselobarbus but also in other large barbs.

Once again, contrary to Basavaraja's observation, the lateral band is clearly visible in both male and female specimens of $H$. pulchellus. Even in formalin fixed or alcohol preserved specimens, the lateral band is visible. In Knight et al. (2013b) good colour photographs have been provided for reference. Other observations of Basavaraja such as the difference in the shape of the lateral line in the dry mount are unjustified as it is quite obvious a dry mount is bound to be distorted. Moreover, the size of scales is different, as the dry mount of Day is over a foot long, while the fish depicted by us is less than half its size.

Though Basavaraja repeatedly mentions about the fish he has collected, he has not provided the image of the fish, rather has shown an obscure black and white photo from some old publication. The picture provided cannot be used to count lateral line scales as the caudal fin base of the fish in question is completely unintelligible. It is also relevant to note that large adults of the genus Hypselobarbus, including $H$. jerdoni, $H$. dobsoni and $H$. thomassi get dark pigmented abdominal scales highlighting the upper body as silvery white. This should however be not confused with the clear band that 
runs along the body of $H$. pulchellus which is apparently clear in even small specimens of less than $100 \mathrm{~mm} \mathrm{SL}$.

We do not understand how Basavaraja can make a statement that "The morphometric, meristic and other data furnished (Table 1) is only secondary" when almost all recently described fish species are diagnosed based on morphometrics and meristics. Moreover, we have also distinguished $H$. pulchellus from $H$. dobsoni based on osteology. The shape of the fifth ceratobranchial shown in Image 3 of Knight et al. (2013b) clearly shows that they are different species.

The inputs compiled by Basavaraja from other scientists, highlight no other fact other than the misconception of $H$. pulchellus and $H$. dobsoni being synonyms. It is not unreasonable, as many other authors (Hora \& Misra 1942; Jayaram 1991; Talwar \& Jhingran 1991; Jayaram 1999; Daniels 2002) have also considered Hypselobarbus pulchellus a synonym of either $H$. dobsoni or $\mathrm{H}$. jerdoni which is incorrect. Interestingly, Jayaram et al. (1982) considered $H$. pulchellus as a valid species and remarked that though Hora \& Misra (1942) synonymised $H$. pulchellus with $H$. jerdoni, it could be clearly distinguished from the latter by a higher lateral line scale count of 30-35 and the relative length of the dorsal fin. During our study, one specimen of $H$. pulchellus collected by Jayaram (ZSI/SRC F 8753) from Tunga River, Shimoga, Karnataka was examined. $H$. pulchellus can be distinguished from $H$. jerdoni based on a shorter dorsal fin length of 20.7-23.3 \% SL (vs. 26.4$30.1 \%$ SL) as rightly observed by Jayaram et al. (1982).

The local name 'Katladi' does find mention in Day (1878) and in our experience, we have known locals to refer to $H$. pulchellus by that name. Correlating the fact that Hypselobarbus pulchellus feeds on grass to the local name 'Hullu gende' is unjustified as in our experience we have found $H$. dobsoni and $H$. jerdoni also preferring plant matter. Even $H$. thomassi and $H$. lithopidos readily take blanched spinach. The identification of fishes from vernacular names is unreliable, as fishes often have a greater variety of local names than any other group of animals (Spence \& Prater 1932), with the same name being used for different species and different names being used for the same species.

The number of specimens examined by us is mentioned in the material examined section in Knight et al. (2013b) and most of our specimens have been deposited in a nationalized museum (ZSI/SRC) where they can be accessed by anyone. It is true that we have not examined any specimen from Basavaraja's repository as pointed out by him. This is because we could neither find any published reference of his repository nor the register numbers of the specimens in his repository.

Nevertheless, it is disheartening to see that all of Basavaraja's assertions are based on his conceptualization of the species and not based on the type specimens. We have examined the photographs of all the three type specimens before we drew inference for our paper. The fish mentioned by Basavaraja as 'female' $H$. pulchellus with 30-31 scales could very well be $H$. dobsoni which is quite common in Tunga River.

We believe Knight et al. (2013b) is comprehensive enough to clarify all the ambiguity mentioned by Basavaraja and establishes the fact that Hypselobarbus pulchellus, $H$. dobsoni and $H$. jersoni are three valid species and are not synonyms of each other as it has been widely believed till now.

\section{References}

Ali, A., S. Philip, N. Dahanukar, C.R. Renjithkumar, A. Bijukumar \& R. Raghavan (2013). Distribution, threats and conservation status of Hypselobarbus thomassi (Day, 1874), a poorly known cyprinid fish of the Western Ghats freshwater ecoregion. Journal of Threatened Taxa 5(17): 5202-5213; http://dx.doi.org/10.11609/JoTT.o3838.5202-13

Basavaraja, N. (2014). Comments on Hypselobarbus pulchellus part of the articles by Knight et al. (2013a,b) published in JoTT. Journal of Threatened Taxa 6(1): 5417-5418; http://dx.doi.org/10.11609/ JoTT.03899.5417-8

Daniels, R.J.R. (2002). Freshwater Fishes of Peninsular India. Universities Press, Hyderabad, India, 288pp.

Day, F. (1870). Notes on some fishes from the western coast of India. Proceedings of the General Meetings for Scientific Business of the Zoological Society of London Pt(2): 369-374.

Day, F. (1878). The Fishes of India; Being a Natural History of the Fishes Known to Inhabit the Seas and Freshwaters of India, Burma and Ceylon. William Dawson\& Sons Ltd., London, $x x+778 p p, 196 p l s$.

Hora, S.L. \& K.S. Misra (1942). Fish of Poona, Part II. Journal of the Bombay Natural History Society 43(2): 218-225.

Jayaram, K.C., T. Venkateswarlu \& M.B. Ragunathan (1982). A Survey of the Cauvery River System with a Major Account of its Fish Fauna. Records of the Zoological Survey of India, Occasional Paper No. 36, $115 p p+12 p l s$.

Jayaram, K.C. (1991). Revision of the Genus Puntius Hamilton from the Indian region (Pisces: Cypriniformes, Cyprinidae, Cyprininae). Records of the Zoological Survey of India Occasional Paper 135: $1-178$.

Jayaram, K.C. (1999). The Freshwater Fishes of the Indian Region. Narendra Publishing House, New Delhi, India, 551pp.

Knight, J.D.M., A. Rai \& R.K.P. D'souza (2013a). Re-description of Hypselobarbus lithopidos (Teleostei: Cyprinidae), based on its rediscovery from the Western Ghats, India, with notes on $H$. thomassi. Journal of Threatened Taxa 5(13): 4734-4742; http:// dx.doi.org/10.11609/JoTT.o3602.4734-42

Knight, J.D.M., A. Rai \& R.K.P. D'souza (2013b). Rediscovery of Hypselobarbus pulchellus, an endemic and threatened barb (Teleostei: Cyprinidae) of the Western Ghats, with notes on $H$. dobsoni and H. jerdoni. Journal of Threatened Taxa 5(17): 51945201; http://dx.doi.org/10.11609/JoTT.03686.5194-201

Spence, R. \& S.H. Prater (1932). Game fishes of Bombay, the Deccan and the neighboring districts of the Bombay Presidency. Journal of Bombay Natural History Society 36: 29-66, 19 pls.

Talwar, P.K. \& A.G. Jhingran (1991). Inland Fishes of India and Adjacent Countries. Vol 1 \& 2. A.A. Balkema, Rotterdam, 541pp.

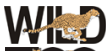

